\title{
Lung Cancer pTis TNM Finding v6 and v7
}

National Cancer Institute

\section{Source}

National Cancer Institute. Lung Cancer pT is TNM Finding v6 and v7. NCI Thesaurus.

Code C60967.

Lung cancer with a finding of carcinoma in situ. (from AJCC 6th and 7th Eds.) 